\title{
TITLE:
}

\section{$<$ Note $>$ Evaluating the Effectiveness of a 10-Year Old Great Ape Conservation Project in Cameroon}

\section{AUTHOR(S):}

Tagg, Nikki; Petre, Charles-Albert; Willie, Jacob

\section{CITATION:}

Tagg, Nikki ...[et al]. < Note> Evaluating the Effectiveness of a 10-Year Old Great Ape Conservation Project in Cameroon. Pan Africa News 2011, 18(2): 20-23

ISSUE DATE:

2011-12

URL:

http://hdl.handle.net/2433/152161

RIGHT:

Copyright (c) Pan Africa News. 
(LR) were also encountered regularly but were rarely seen grooming with other males. These preliminary observations suggest JL and KT-who both received submissive behavior from other males, including the largest male SL - had a GHC "partnership" ${ }^{10}$. More data are evidently needed, but we may tentatively classify GHC as 'habitual' at Bulindi ${ }^{4}$.

While GHC occurs at Bulindi, it has not been seen $25 \mathrm{~km}$ north in the Sonso community at Budongo ${ }^{11}$. GHC has not previously been reported present in one community yet absent in another so nearby (Mahale, where it occurs, and Gombe, where it does not, are separated by $150 \mathrm{~km}$; Kibale, where it occurs, and Sonso, where it does not, are $170 \mathrm{~km}$ apart). GHC has also not been seen in the small Kasokwa community bordering the southern edge of Budongo (Janette Wallis, pers. comm.) (see Figure 1). Bulindi chimpanzees use tools to excavate subterranean bee nests for honey - a behavior not recorded at Sonso or elsewhere in western Uganda ${ }^{12}$. The occurrence of GHC at Bulindi provides further evidence of behavioral variation among chimpanzees in the Budongo region. Multiple small chimpanzee groups inhabit forests patches within the cultivated landscape south of Budongo ${ }^{13}$. Chimpanzees occur north of Bulindi, closer to Budongo's southern border (e.g. around Kasongoire Forest Reserve). Future studies should aim to establish the status of GHC among chimpanzees in this intervening area.

GHC was first identified in 5/8 (63\%) long-term study communities ${ }^{4}$. An expanded data-set reveals it occurs in 14/17 communities (82\%), including two Pan paniscus communities $^{5,8,14}$. If we include Bulindi and Kasokwa it occurs in 15/19 (79\%). This suggests GHC is usually present in wild populations. Nevertheless, it is easier to confirm presence than absence in unhabituated or semihabituated communities. Despite the emerging high prevalence of GHC in wild chimpanzees, the evidence for its absence at three sites (Bossou, Gombe, Sonso) is firmit has not been seen at these sites in decades of fieldwork. GHC has emerged spontaneously in one captive colony ${ }^{15}$ and possibly one sanctuary-released group ${ }^{9}$. This indicates $\mathrm{GHC}$ is a dynamic social custom that potentially emerges and disappears in local populations repeatedly over time.

\section{ACKNOWLEDGEMENTS}

I thank the President's Office, the Uganda National Council for Science and Technology, and Uganda Wildlife Authority for permission to work in Uganda. Dan Balemesa, Gerald Mayanda, Tom Sabiiti, Moses Ssemahunge and Jane Stokoe helped in the field. Research was funded by the ESRC and NERC, and the Leverhulme Trust (project reference: F/00 $382 / \mathrm{F}$ ). The manuscript was improved by comments from W.C. McGrew.

\section{REFERENCES}

1. McGrew WC, Tutin CEG 1978. Evidence for a social custom in wild chimpanzees? Man 13:234-251.

2. McGrew WC, Marchant LF, Scott SE, Tutin CEG 2001. Intergroup differences in a social custom of wild chimpanzees: The grooming hand-clasp of the Mahale Mountains. Curr Anthropol 42:148-153.

3. Nakamura M, Uehara S 2004. Proximate factors of different types of grooming hand-clasp in Mahale chimpanzees: Implications for chimpanzee social customs. Curr Anthropol 45:108-114.
4. Whiten A, Goodall J, McGrew WC, Nishida T, Reynolds V, Sugiyama Y, Tutin CEG, Wrangham RW, Boesch C 2001. Charting cultural variation in chimpanzees. Behaviour 138:1481-1516.

5. Nakamura M 2002. Grooming-hand-clasp in Mahale M Group chimpanzees: Implications for culture in social behaviours. In: Behavioural Diversity in Chimpanzees and Bonobos. Boesch C, Hohmann G, Marchant LF (eds), Cambridge University Press, Cambridge, pp. 71-83.

6. McLennan MR 2010. Case study of an unusual humanchimpanzee conflict at Bulindi, Uganda. Pan Afr News 17:1-4.

7. McLennan MR, Hill CM 2010. Chimpanzee responses to researchers in a disturbed forest-farm mosaic at Bulindi, western Uganda. Am J Primatol 72:907-908.

8. Webster TH, Hodson PR, Hunt KD 2009. Grooming handclasp by chimpanzees of the Mugiri community, ToroSemliki Wildlife Reserve, Uganda. Pan Afr News 16:5-7.

9. Humle T, Colin C, Raballand E 2009. Preliminary report on hand-clasp grooming in sanctuary-released chimpanzees, Haut Niger National Park, Guinea. Pan Afr News 16:7-10.

10. Bonnie KE, de Waal FBM 2006. Affiliation promotes the transmission of a social custom: Hand-clasp grooming among captive chimpanzees. Primates 47:27-34.

11. Reynolds V 2005. The Chimpanzees of the Budongo Forest. Oxford University Press, Oxford.

12. McLennan MR 2011. Tool-use to obtain honey by chimpanzees at Bulindi: New record from Uganda. Primates 52:315-322.

13. McLennan MR 2008. Beleaguered chimpanzees in the agricultural district of Hoima, western Uganda. Primate Conserv 23:45-54.

14. Fruth BI, Hohmann G, Beuerlein MM, McGrew WC 2006. Grooming hand clasp by bonobos of Lui Kotal, Democratic Republic of Congo. Pan Afr News 13:6-8.

15. de Waal FBM, Seres M 1997. Propagation of handclasp grooming among captive chimpanzees. Am J Primatol 43:339-346.

\section{<NOTE>}

\section{Evaluating the Effectiveness of a 10-Year Old Great Ape Conservation Project in Cameroon}

\author{
Nikki Tagg ${ }^{1,2}$, Charles-Albert \\ Petre $^{3,4} \&$ Jacob Willie ${ }^{1}$ \\ 1 Projet Grands Singes, Cameroon, Cameroon. \\ 2 Centre for Research and Conservation, Royal Zoological \\ Society of Antwerp, Belgium. \\ 3 Liège University, Belgium. \\ 4 Gembloux Agro-Bio Tech, Belgium. \\ (E-mail: Nikki.tagg@kmda.org)
}

The world faces a massive human-accelerated biodiversity decline. Western lowland gorillas (Gorilla gorilla gorilla) and central chimpanzees (Pan troglodytes troglodytes) are heavily concerned by this decline, with a range-wide mean of $50 \%$ having perished ${ }^{1,2}$, due to hunting for meat, disease and habitat loss and disturbance ${ }^{3,4,5,6}$. A large majority (approximately 80\%) of all remaining populations of chimpanzees and gorillas live outside protected areas (PAs) ${ }^{7,8}$ where human pressures are high. A serious everyday threat to great ape survival is hunting for meat ${ }^{3}$ and as a result of the poverty of an ever-growing 


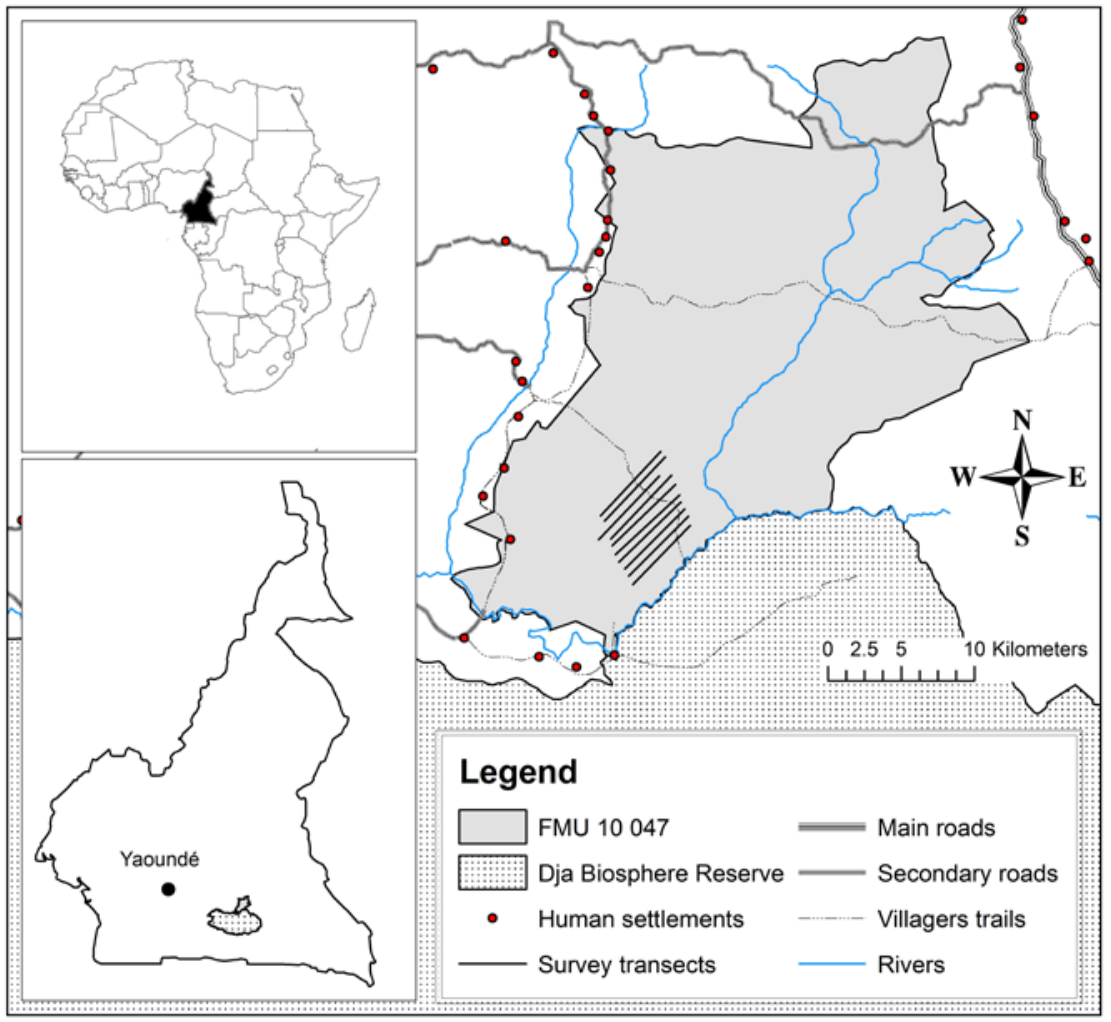

Figure 1. PGS study site in the northern periphery of the Dja Biosphere Reserve, Cameroon.

local population with a taste for game meat, traditional bushmeat hunting has become more and more driven by economic forces ${ }^{9}$. In the Dja Biosphere Reserve (DBR) it has been noted that all large and medium-sized mammalian species (except galagos and pottos) are hunted for human consumption ${ }^{10}$; that wildlife is the source of $98 \%$ of the animal protein consumed in villages and towns in the vicinity; and that game meat comprises close to $80 \%$ of all meat eaten by the inhabitants - a large portion of this meat acquired through poaching in the reserve ${ }^{11}$. Severe effects on animal populations can result, leading to decline and extinction of even small-bodied, fastreproducing species that were previously thought of as being insusceptible to the pressures of hunting, for example some duiker species ${ }^{10,12}$. Great apes are especially vulnerable to high hunting pressures impacting negatively on their populations, as they are large-bodied animals with slow reproductive rates, and they cannot rapidly recuperate from losses ${ }^{1}$.

Projet Grands Singes (PGS) of the Royal Zoological Society of Antwerp (RZSA), Belgium, seeks to promote wildlife conservation and decelerate the rate of decline of species such as great apes in this region with communitybased interdependent conservation and development objectives ${ }^{13}$. PGS works in a non-protected forest in the buffer zone of the Dja Biosphere Reserve (DBR; see Figure 1), which is considered as an 'exceptional priority area' for great ape conservation as a result of its size $\left(5,260 \mathrm{~km}^{2}\right)$, rich biodiversity, and estimated large population size of great apes ${ }^{14}$ but in recent years, UNESCO has threatened to declassify the reserve as a result of limited action on the ground ${ }^{15}$. Being the sole great ape conservation and research project in the northern periphery of the DBR,
PGS adopts an important multi-layered approach in its management of the site: including awareness programmes, control of poaching, supply of alternative incomes and recognition of rights of local people ${ }^{16}$. In this area, rural communities of Baka and Bantu (Badjoue tribe) are amongst the poorest $(<\$ 1 /$ d), least developed (infrastructure like roads, schools and health centres lacking) and least educated (literacy and rates of school attendance) in the country. PGS aids communities to develop participative sustainable hunting management plans to ensure livelihood security and an improved social and economic well-being ${ }^{17}$, as well as contributing to the maintenance of biodiversity; a method that has been suggested as being crucial, in conjunction with government-led mechanisms for monitoring and law enforcement, in the maintenance of sustainability of bushmeat harvesting ${ }^{18}$. Secondly, PGS provides small-scale development training and financial aid for the local people, in an attempt to reduce poverty and aid in wildlife protection ${ }^{19,20}$. Finally and crucially, PGS uses scientific research as a conservation tool to forge a rare and important direct link between conservation and benefits for the local communities ${ }^{21}$. International researchers use established research facilities to contribute to knowledge of great apes, inarguably crucial to the conservation of any species $^{2}$, while regular employment of local people in research activities reinforces the value of living wildlife and intact forests to the community. Furthermore, the presence of the camp and staff acts as a deterrent to poachers, and in effect offers the site "semi-protection"22. Additional project activities including sensitisation to wildlife laws and conservation benefits, and investments in anti-poaching actions led by local authorities, further contribute to the better understanding and capacity of the local population to embrace great ape conservation in their forests.

However the extent and effectiveness of conservation projects such as PGS are poorly known ${ }^{20}$ and the pressing need of evaluation and evidence of success remains ${ }^{18,23-25}$. Such evaluation is crucial for planning, refinement and assessment of the effectiveness of conservation approaches $^{26}$. There is an urgent need to conduct extensive, regular and coordinated evaluation of all conservation efforts, including repeated surveys of great ape density and abundance and hunting pressures in the locality ${ }^{27}$, as well as reporting on outcomes such as technical feasibility, economic sustainability, social appropriation, and conservation outcomes ${ }^{18}$ in order to ensure the feasibility of participative conservation actions in such non-protected buffer zones.

It has become evident in the PGS site that gun hunting has dramatically increased in the locality (unpublished data), in accordance with documented trends ${ }^{3}$. This is due 
to easier access to homemade cheap and effective shotguns in recent years; and better accessibility to rural areas as a result of an influx of cheap motorbikes allowing buyers from towns and cities to leave commands - and the ammunition required-with local people $\mathrm{e}^{10,28}$. Furthermore, in accordance with this increase in gun hunting, more bushmeat being taken from the forests is being sold than in previous years; non-great ape primates are occurring more often in the bushmeat taken from the forest; primates are mostly being caught with guns; and the majority of these primates are being sold (unpublished data). This suggests that the bushmeat markets in the region are becoming more and more commercialised $^{9,10}$, in keeping with the documented increase in intensity and spatial extent of commercial hunting which has been gradually taking hold for decades ${ }^{1}$.

This change in hunting in the region shows the seriousness of threats and pressures being exerted on great ape populations in non-protected forests over the last decade. It is this commercial bushmeat trade that wipes out species ${ }^{10}$. Furthermore, amongst tribes in this locality the hunting of apes is not a traditional taboo: ape meat is readily consumed and ape bones are used for traditional mystic practices. As a result, the demand for bushmeat is high and human population density continues to rise $\mathrm{e}^{3}$, meaning that hunting pressure represents a serious threat to the viability of the local great ape population. Great apes produce one offspring every four to five years, when their previous offspring is weaned, so the rate of weaned individuals being killed by hunters with guns can easily be higher than the rate of replacement ${ }^{1}$. If apes in the PGS site had been subject to such intensifying hunting pressures since its launch 10 years ago, we might expect to see a huge decline in great ape numbers in this time, or even local extirpation. Studies in sites across the extent of great ape range have shown such declines in great ape nest encounter rates (eg, 90\% in 17 years in Ivory Coast ${ }^{1,14,29,30}$ ). However, encounter rates per kilometre (ERKs) of chimpanzees and gorilla nest sites in the PGS site in the buffer zone of the DBR did not significantly change between the launch of PGS in 2001 and later surveys in 2008 (paired sample t-tests: chimpanzee $p=0.579$; gorilla $p=0.260$; see Table 1). This implies that the abundance of chimpanzees and gorillas has remained stable despite the increase in gun hunting in the area, suggesting that there has been a check on the negative impacts of hunting on great ape populations during this timeframe ${ }^{10}$.

This check on great ape hunting is suggested to be due to the multi-layered and long term approach of PGS. Its myriad of conservation and development activities have resulted in a local amnesty on great ape killing in the focal area and suggest that, even in non-protected and heavily-used forests, it is not too late. Such conservation projects are highly capable of having a positive effect on the protection of biodiversity, in particular great apes, and

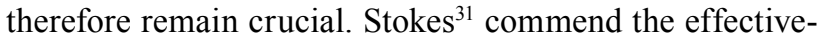
ness of initiatives to reduce poaching and protect habitats in the maintenance of high abundances of great apes and elephants. Others say it cannot be denied that such conservation actions (including education, livelihoods, incentives and capacity-building) are important $\mathrm{t}^{16,20,32}$ and thatquite simply - there is hope.

\section{REFERENCES}

1. Walsh PD, Abernethy KA, Bermejo M, Beyers R, De Wachter P, Ella Akou M, Huijbregts B, Idiata Mambounga D, Kamdem Toham A, Kilbourn AM, Lahm SA, Latour S, Maisels F, Mbina C, Mihindou Y, Ndong Obiang S, Ntsame Effa E, Starkey MP, Telfer P, Thibault M, Tutin CEG, White LJT, Wilkie DS 2003. Catastrophic ape decline in western Equatorial Africa. Nature 422:611-614.

2. Stokes EJ 2008. Conservation through scientific collaboration: case study-western-gorilla.org. In: Conservation in the 21st Century: Gorillas as a Case Study. Stoinski, Steklis HD, Mehlman PT (eds). Springer, New York, pp. 296-314.

3. Wilkie DS, Carpenter JF 1999. Bushmeat hunting in the Congo Basin: an assessment of impacts and options for mitigation. Biodivers Conserv 8:927-955.

4. Bassey AE, Oates JF (eds) 2001. Proceedings of the International Workshop and Conference on the Conservation of the Cross River Gorillas. Calabar, Nigeria, April 6-9, 2001.

5. Kondgen S, Kuhl H, N'Goran P, Walsh PD, Schenk S, Ernst N, Biek R, Formenty P, Matz-Rensing K, Schweiger B, Junglen S, Ellerbrok H, Nitsche A, Briese T, Lipkin WI, Pauli G, Boesch C, Leendertz FH 2008. Pandemic human viruses cause decline of endangered great apes. Curr Biol 18:1-5.

6. Bermejo M, Rodriguez-Teijeiro JD, Illera G, Barroso A, Vila C, Walsh PD 2006. Ebola outbreak killed 5000 gorillas. Science 314:1564.

7. Morgan D, Sanz C 2007. Best Practice Guidelines for Reducing the Impact of Commercial Logging on Great Apes in Western Equatorial Africa. Gland, Switzerland: IUCN SSC Primate Specialist Group.

8. Poulsen JR, Clark CJ 2004. Densities, distributions and seasonal movements of gorillas and chimpanzees in swamp forest in Northern Congo. Int J Primatol 25:285-306.

9. Chapman C, Peres C 2001. Primate conservation in the New Millenium: The role of scientists. Evol Anthropol 10:16-33.

10. Muchaal PK, Nandjui G 1999. Impact of village hunting on wildlife populations in the Western Dja Reserve, Cameroon. Conserv Biol 13:385-396.

11. Koulagna DK 2001. Country report: The issue of bushmeat in Cameroon. Bushmeat Crisis Task Force CAP Meeting Proceedings (www.bushmeat.org/may2001.htm). 
12. Fa JE, Juste J, Perez del Val J, Castroviejo J 1995. Impact of market hunting on mammal species in Equatorial Guinea. Conserv Biol 9:1107-1115.

13. Salasfky N 2011. Integrating development with conservation. Biol Conserv 144:973-978.

14. Tutin CEG, Parnell RJ, White LJT, Fernandez M 1995. Nest building by lowland gorillas in the Lopé Reserve, Gabon: environmental influences and implications for censusing. Int J Primatol 16:53-76.

15. World Heritage (2011) Convention Concerning the Protection of the World Cultural and Natural Heritage. 35Com (http://whc.unesco.org/en/decisions/4409)

16. Vermeulen C, Julve C, Doucet J-L, Monticelli D 2009. Community hunting in logging concessions: Towards a management model for Cameroon's dense forests. Biodivers Conserv 18:2705-2718.

17. Roe D, Nelson F, Sandbrook C (eds) 2009. Community Management of Natural Resources in Africa: Impacts, Experiences and Future Directions. IIED Natural Resource Issues No. 18.

18. Van Vliet N, Milner-Gulland EJ, Bousquet F, Saqalli M, Nasi R 2010. Effect of small-scale heterogeneity of prey and hunter distributions on the sustainability of bushmeat hunting. Conserv Biol 24:1327-1337.

19. Sandbrook C, Roe D 2010. Linking conservation and poverty alleviation: the case of great apes. An overview of current policy and practice in Africa. Conservation and Poverty Learning Group Report.

20. Brooks TM, Wright J, Sheil D 2009. Evaluating the success of conservation actions in safeguarding tropical forest biodiversity. Conserv Biol 23:1448-1457.

21. Nepal S, Spiteri A 2011. Linking livelihoods and conservation: An examination of local residents' perceived linkages between conservation and livelihoods benefits around Nepal's Chitwan National Park. Environ Manage 47:727-738.

22. Williamson EA, Usongo L 1995. I. Survey of primate populations and large mammal inventory ; II. Survey of elephants, gorillas and chimpanzees; Reserve de Faune du Dja, Cameroun. Projet ECOFAC-Composante Cameroun.

23. Ferraro PJ, Patanayak SK 2006. Money for nothing? A call for empirical evaluation of biodiversity conservation investments. PLOS Biol 4:482-488; e105.

24. Pullin AS, Knight TM 2009. Doing more good than harm -Building an evidence-base for conservation and environmental management. Biol Conserv 142:931-934.

25. Sutherland WJ, Pullin AS, Dolman PM, Knight TM 2004. The need for evidence-based conservation. Trends Ecol Evol 19(8):305-308.

26. Matthews E, Matthews A 2004. Survey of gorillas (Gorilla gorilla gorilla) and chimpanzees (Pan troglodytes troglodytres) in Southwestern Cameroon. Primates 45:15-24.

27. Kühl H, Maisels F, Ancrenaz M, Williamson EA 2008. Best Practice Guidelines for Surveys and Monitoring of Great Ape Populations. Gland, Switzerland: IUCN SSC Primate Specialist Group.

28. Willie J 2006. Contribution a l'evaluation de l'incidence de la chasse sur les populations de cephalophes de la peripherie nord de la reserve de biosphere du Dja (Est-Cameroun). Master's thesis, University of Dschang, Cameroon.

29. Campbell G, Kuhl H, N'Goran Kouame P, Boesch C 2008. Alarming decline of West African chimpanzees in Cote d'Ivoire. Curr Biol 18:R903/04.

30. Kormos R, Boesch C, Bakarr MI, Butynski TM 2003. West African Chimpanzees: Status Survey and Conservation Action Plan. IUCN/SSC Primate Specialist Group, Gland, Switzerland.

31. Stokes EJ, Strindberg S, Bakabana PC, Elkan PW, Iyenguet FC, et al. 2010. Monitoring great ape and elephant abundance at large spatial scales: Measuring effectiveness of a conservation landscape. PLOS ONE 5:e10294.

32. Posa MRC, Diesmos AC, Sodhi NS, Brooks TM 2008. Hope for threatened tropical biodiversity: lessons from the Philippines. BioScience 58:231-240.

<NOTE>

\section{Chimpanzees in Bandafassi Arrondissement, Southeastern Senegal: Field Surveys as a Basis for the Sustainable Community- Based Conservation}

\author{
Maja Gašperšičc \& Jill D. Pruetz ${ }^{2}$ \\ 1 Department of Biology, University of Ljubljana, Slovenia \\ 2 Department of Anthropology, Iowa State University, USA \\ (E-mail: maja.g.cisse@gmail.com)
}

\section{INTRODUCTION}

The western chimpanzee (Pan troglodytes verus) is considered as one of the most threatened ape species, facing a dramatic decline over the last decade ${ }^{1,2}$. The latest conservation action plans classified Senegal as "an exceptionally important priority area" for chimpanzee protection, which demands immediate attention ${ }^{3}$. Chimpanzees have been expatriated from at least two African countries and IUCN estimated the Senegalese population to be almost extinct, numbering between 200 and 4004. Most apes range in small isolated communities in intense sympatry with local ethnic groups. Major threats include human encroachment, deforestation for crops, gold and iron digging, along with limited pet trade ${ }^{5}$. Additionally, this population lives at the northern edge of species' distribution, in extremely hot, dry and open savanna landscape that characterized an important transitional period in human evolution ${ }^{6}$. Chimpanzees though have a mythical relation with Senegalese people; therefore local folklore and taboos allows them to share space. This project is part of the investigation "Conservation of chimpanzees in south-eastern Senegal: the human element" supervised by JD Pruetz. Initially, we identified ape communities in Bandafassi Arrondissement, their ranging patterns, key water and food sources, and particularly chimpanzees' relation to humans via an ethnoprimatological approach ${ }^{7}$.

Due to the importance of water sources with gallery forests, specific food-rich areas, and conflicts with humans encountered we focused on three priority fieldsites: mountain slopes above Bandafassi village, where chimpanzees were known to attack goats; the stream of Angafou $\left(12^{\circ} 34^{\prime} \mathrm{N}, 12^{\circ} 24^{\prime} \mathrm{W}\right)$, its rich gallery forest and mango orchards, being crop-raided by apes, supposedly after commercial harvesting of baobab and Saba fruits increased; and the surroundings of Nathia $\left(12^{\circ} 29^{\prime} \mathrm{N}\right.$, $12^{\circ} 22^{\prime} \mathrm{W}$ ), which was not identified in previous surveys ${ }^{2}$ and shows no conflict between species. Two buffer-zones are surveyed sporadically to provide basic information about the presence of chimpanzees in the remaining forest patches between the Niokolo Koba national park and neighboring Guinea-Conakry. Several sites along Gambia River indicate various conflicts between chimpanzees and humans (e.g. palm-wine harvesting, raphia or bamboocutting, artisanal gold-digging sites). Chimpanzees are seen there only when people are not common, and it appears that their seasonal activity affects the ranging patterns of apes. 